Chemistry: Prof. T. Erdei-Gruz, for investigations of catalytic and corrosive processes ; Prof. G. Fodor, for work on the stereometric structure of organic compounds and for the synthesis of certain medicines ; and Prof. Z. Szabo, for work on the theory of the mechanism of reactions important to industry.

Medicine : Prof. G. Hetényi, for investigation of correlations between the brain and stomach ulcer; Prof. J. Szentágothai, for the investigation of correlations between the labyrinth and the action of the eye-muscles; I. Kemény, chief medical officer, for work in connexion with lower dentures prepared on the basis of anatomical and physiological investigations.

Technology: M. Freund, for the production of lubricating oils, washing powders and wax substitutes from Hungarian mineral oil ; Prof. J. Varga, for the conversion of Hungarian mineral oils into aromatic compounds; E. Winter, for work on the technology of radio waves; and Prof. G. Tarján and K. Martini, engineer, for work on the conversion of coal from the Komlo mines into coke.

Technical Reconstruction: K. P. Pfeiffer, engineer: (20,000 forints), for innovations in the methods of gasification of lignite and in gas generators; $\mathbf{A}$. Gerecs and J. Kolonics, chemists $(20,000$ forints jointly), the former for making possible the production of vitamin $\mathbf{P}$, vitamin $\mathbf{B}_{1}$, pyrocatechin, papaverin and $p$-amino-salicylic acid (for use in treating tuberculosis) from Hungarian raw materials, and the latter for important innovations in the production of 'ultraseptil' (sulphanyl drugs) and papaverin preparations ; L. M. Zsolnai, chemist, for the substitution of Hungarian raw materials for imported material for the manufacture of porcelain insulators; M. Fülöp, technician, for several innovations, one of which-spongy hard chromium plating-involves an annual saving of $1,700,000$ forints; L. Frank, foundry engineer, for his innovations in connexion with the casting of grey iron, which increased twofold the tensile strength of grey iron.

\section{U.S. NATIONAL ACADEMY OF SCIENCES}

\section{ANNUAL MEETING}

$\mathrm{T}$

HE National Academy of Sciences, at its annual meoting held in Washington, D.C., during April 24-26, elected the following officers, new members and foreign associates.

President for a four-year term ending in 1954 : Detlev W. Bronk, president of Johns Hopkins University and chairman of the United States National Research Council.

Foreign Secretary for a four-year term ending in 1954: Roger Adams, head of the Department of Chemistry, University of Illinois.

Members of the Council of the Academy, for a threeyear term ending in 1953: Oliver E. Buckley, president of the Bell Telephone Laboratories; and Walter S. Hunter, chairman of the Department of Psychology, Brown University.

New Members : Francis Birch, professor of geophysies, Harvard University ; S. Bochner, professor of mathematics, Princeton University; James Bonner, professor of biology, California Institute of Technology ; Ernst Cloos, professor of structural geology, Johns Hopkins University ; Lyman C. Craig, member of Rockefeller Institute for Medical Research, New
York ; Lester R. Dragstedt, chairman of the Department of Surgery, University of Chicago ; David R. Goddard, chairman of the Department of Botany, University of Pennsylvania; Herbert S. Harned, professor of chemistry, Yale University ; G. Evelyn Hutchinson, director of graduate studies in zoology, Yale University; M. R. Irwin, professor of genetics, University of Wisconsin ; E. C. Kendall, head of the Section on Biochemistry, Mayo Clinic, Rochester ; Gerard P. Kuiper, professor of astronomy, Yerkes Observatory, University of Chicago; W. F. Libby, professor, Institute for Nuclear Research, University of Chicago; Fritz A. Lipmann, head of the Biochemical Research Laboratory, Massachusetts General Hospital, Boston; R. Lorente de No, member of Rockefeller Institute for Medical Research, New York; Frank C. Mann, professor of experimental medicine, Mayo Foundation, University of Minnesota; Kenneth F. Maxcy, professor of epidemiology, School of Hygiene and Public Health, Johns Hopkins University ; C. E. Kenneth Mees, director and vicepresident in charge of research, Eastman Kodak Co., Rochester ; E. V. Murphree, president and director, Standard Oil Development Co., 15 West 5lst Street, New York; Alfred O. Nier, professor of physics, University of Minnesota ; Arthur E. Raymond, vicepresident and director, Douglas Aircraft Co., Inc., Santa Monica; Bruno B. Rossi, professor of physics, Massachusetts Institute of Technology; B. F. Skinner, professor of psychology, Harvard University ; J. A. Stratton, provost of the Massachusetts Institute of Technology; Victor C. Twitty, chairman of the Department of Zoology, Stanford University ; George Wald, professor of biology, Harvard University; Howel Williams, chairman of the Department of Geological Sciences, University of California ; Ralph E. Wilson, astronomer, Mount Wilson Observatory, Pasadena; Oskar Wintersteiner, head of the Division of Organic Chemistry, Squibb Institute for Medical Research, New Brunswick ; and M. L. Wolfrom, head of the Division of Organic Chemistry, Ohio State University.

Foreign Associates : C. H. Best, director of the Banting and Best Department of Medical Research, University of Toronto ; and A. J. Kluyver, professor of microbiology, Technical University of Delft.

\section{Medal Awards}

The Academy has made the following medal awards.

Henry Draper Gold Medal for 1949, to Prof. Otto Struve, Andrew MacLeish distinguished service professor and chairman of the Department of Astronomy, University of Chicago, in recognition of his contributions to astronomical physies, the most notable of which are his observations of stars with peculiar spectra and his development of theories of the structure of stellar atmospheres.

Daniel Giraud Elliot Gold Medal for 1946, to Dr. Robert Broom, keeper of vertebrate palæontology and anthropology, Transvaal Museum, in recognition of his many scientific articles and books, particularly his part in the book entitled "The South African Fossil Ape-Men, the Australopithecinæ", which was published in 1946.

Mary Clark Thompson Gold Medal for 1949, to Dr. Lauge Koch, of Copenhagen, for most important services to geology and palæontology, by his organisation and pursuit of exploration and geological studies in East Greenland, often under the most arduous conditions. 